\title{
Źródła dochodów klasztoru klarysek w Gnieźnie pod koniec XVI wieku na podstawie rękopisu „Regestrum 1593”
}

\begin{abstract}
Słowa kluczowe: nowożytność, monastycyzm, gospodarka, klaryski, Gniezno
Key words: early-modern period, monasticism, economy, Poor Clares, Gniezno
\end{abstract}

Organizacja dóbr, zarządzanie nimi, kwestie dochodowości gospodarki klasztornej w nowożytności to jedno z zagadnień, które do tej pory nie znalazło należytego miejsca w badaniach nad monastycyzmem, zarówno w Polsce, jak i w Europie ${ }^{1}$. Poruszano tę problematykę w odniesieniu do średniowiecza, skupiając się jednak głównie na wielkości uposażenia, bo tego typu informacje zawierają dokumenty, rzadziej zaś włączano do nurtu zainteresowań kwestie ekonomiki i dochodowości. Publikacje na temat gospodarczej działalności zakonów w epoce nowożytnej dotyczyły przede wszystkim cystersów i benedyktynów, dopiero niedawno rozszerzono je na inne zgromadzenia, w tym mendykanckie ${ }^{2}$.

Problematyce gospodarczo-ekonomicznej klasztorów żeńskich, nie tylko w średniowieczu, ale także w nowożytności, poświęcono do tej pory zdecydowanie mniej uwagi niż wspólnotom męskim. W literaturze krajowej tematykę gospodarczą w dobie nowożytnej, bardzo zróżnicowaną pod względem poruszanych zagadnień, prezentują od lat przede wszystkim Anna Szylar, Patrycja Gąsiorowska oraz autorka niniejszego artykułu ${ }^{3}$. Małgorzata Borkowska, pionierka studiów na monastycyzmem żeńskim w epoce staropolskiej, nakreśliła obszar badawczy. Jest on znacznie szerszy w porównaniu do perspektyw i możliwości, jakie stwarzają źródła średniowieczne, ze względu na wzrost liczebności, a przede wszystkim zróżnicowanie bazy źródłowej zachowanej od XVI stulecia ${ }^{4}$. To przede wszystkim rachunki — zbiorcze wspólnoty bądź poszczególnych urzędniczek/urzędników: ksieni/opata, szafarki/szafarza, kuchmistrza/ekonomki oraz poszczególnych kategorii produktów, np. zboża, żywności, materiałów budowlanych ${ }^{5}$.

${ }^{1}$ W publikacji Klasztor w gospodarce średniowiecznej i nowożytnej 17 spośród 39 artykułów dotyczy epoki nowożytnej (do końca XVIII w.), ale tylko sześć zgromadzeń żeńskich w tym okresie (siódmy przedstawia realia pierwszej połowy XIX w.). Na problem braku spójnego kwestionariusza badań nad gospodarką klasztorną w czasach nowożytnych zwrócił uwagę Maciej Zdanek (Zdanek M. 2009, s. 173-174; Zdanek M. 2013, s. 269), analizując dochody cystersów w Mogile, stwierdził: „Nie ma też podobnych szacunków dla innych klasztorów [...]. Istnieje więc pilna potrzeba rozwijania kwerend archiwalnych i badań nad gospodarką klasztorną XIV-XVI w. [...]”"

2 Dobosz J., Wyrwa A.M. 1999, s. 189-212; Zdanek M. 2005, s. 263-279; Zdanek M. 2011, s. 259-271; a także Little L.K. 1978; Mäkinen V. 2001; Felskau Ch.-F. 2013, s. 27-54; Kubicki R. 2013, s. 55-65.

3 Szylar A. 2005, s. 167-189; Szylar A. 2008; Szylar A. 2013, s. 447-460; Gąsiorowska P. 2010, s. 394 406; Gąsiorowska P. 2011, s. 537-557; Gąsiorowska P. 2013, s. 303-318; Przybyłowicz O.M. 2011, s. 107-130; Przybyłowicz O.M. 2013a, s. 101-114; Przybyłowicz O.M. 2016c, s. 22 i n.; Przybyłowicz O.M. 2017a, s. 446-460.

${ }^{4}$ Borkowska M. 1992, s. 33-39. Zajmowała się aspektami gospodarczymi w niewielkim stopniu, a głównym nurtem jej badań były prozopografia, obyczaje i duchowość.

5 Röhrig F. 1980, s. 217-224; Dochody i wydatki. 2002-2004. 
W tych pierwszych, kilkudziesięcio- lub nawet kilkusetstronicowych kodeksach wpisywano najczęściej po jednej stronie wydatki, zaś po drugiej, od końca rękopisu, przychody w danym okresie, np. kilku bądź nawet kilkudziesięciu lat. Ponadto zachowały się inwentarze dóbr i dochodów, dokumenty dzierżaw, zamian i sprzedaży majątków, księgi legatów i testamentów oraz akta sądowe, wreszcie źródła narracyjne: kroniki, relacje przełożonych zakonnych i biskupów, w tym wizytacje dotyczące w mniejszym bądź większym stopniu kwestii ekonomiczno-gospodarczych poszczególnych wspólnot ${ }^{6}$. Większość z nich znajduje się w archiwach klasztornych istniejących do dziś konwentów, natomiast część — choć mniejsza — w archiwach kościelnych, państwowych i miejskich. Ta druga sytuacja dotyczy przede wszystkim klasztorów zniesionych w trakcie kasat w XVIII i XIX w. na terenie Rzeczpospolitej, a następnie trzech zaborów. Tak jest w przypadku klarysek w Gnieźnie, konwentu zlikwidowanego formalnie decyzją władz pruskich, rozporządzeniem o kasacie klasztorów w prowincji poznańskiej z 31 marca 1833 r. Wiele, zapewne większość archiwaliów tej wspólnoty trafiło w XIX stuleciu do Archiwum Kapituły Metropolitalnej w Gnieźnie, obecnie funkcjonującego jako Archiwum Archidiecezjalne w Gnieźnie (dalej cyt.: AAG) ${ }^{8}$.

Klasztor klarysek w Gnieźnie, będący od lat przedmiotem moich zainteresowań, wydaje się być odpowiednim obiektem do prowadzenia badań nad gospodarką i ekonomiką, ze względu na liczebność i stan zachowanych w AAG źródeł ${ }^{9}$. Ponieważ spuściznę rękopiśmienną prezentowałam już w dwóch artykułach, wspomnę jedynie, że podstawę analizy problematyki gospodarczej stanowią: bogaty zbiór w zespole Kapituła Metropolitalna Akta Luźne (Klaryski Gniezno, A. Cap. Luzy O 14-52, ponad 2500 akt i 4000 kart), dziesięć kodeksów ekspensów illub perceptów począwszy od najstarszej księgi z roku 1613 (trzy z nich umieszczono w serii Zakon Klarysek Gniezno, a siedem w zespole A. Cap. B), ponadto dziewięć poszytów z drugiej połowy XVIII w., stanowiących rozliczenia finansowe konwentu z miastem klasztornym Kostrzynem, jak również 15 inwentarzy — rewizji dóbr ziemskich z XVII stulecia wpisanych na karty kodeksu „Księgi wszystkich spraw konwentu gnieźnieńskiego zakonu Ś. Klary [...] 1609”'10.

Kolejnym, jednym z najcenniejszych źródeł ze względu na czas powstania i zawartość, jest rejestr dochodów - czynszów z dóbr konwentu z roku 1593 „Regestrum censuum de bonis Monialium S[ancate] Clarae Gnesn[ensis] 1593”"11 (dalej cyt.: „Regestrum 1593”). Na jego podstawie zamierzam zrekonstruować strukturę dochodów wspólnoty na początku epoki nowożytnej. Niestety dla tego okresu nie zachowały się inne źródła gnieźnieńskie prezentujące dane gospodarcze, pozwalające na odtworzenie budżetu, w tym tak istotne jak: akta luźne odnoszące się do spraw zarządzania własnością ziemską, zawierające informacje o dzierżawach, zobowiązaniach pieniężnych i naturaliach przekazywanych klasztorowi, oraz rachunki prezentujące różne źródła dochodów, w tym wydatki na potrzeby wspólnoty. Bardzo niewiele do badań

${ }^{6}$ Kaczmarek K. 2013, s. 91-100 wymienia również księgi intencji i opłat mszalnych, na które jednak podczas kwerendy w archiwaliach żeńskich konwentów nigdy nie natrafiłam. O rachunkach średniowiecznych klasztorów z terenu Węgier, zob.: Piwowarczyk E. 2013, s. 201-211; Romhanyi B. 2013, s. 77-96.

7 Do wykonania i wprowadzenia rozkazu gabinetowego wydanego przez prezesa prowincji poznańskiej Edwarda Flottwella w stosunku do klarysek doszło w styczniu 1837 r. (Akta kościoła św. Trójcy. 1835-1871). Informację przekazał mi brat Zbigniew Joskowski OFMConv., badający spuściznę rękopiśmienną gnieźnieńskich franciszkanów. De facto zgromadzenie istniało do 16 stycznia 1865 r., gdy zmarła ostatnia zakonnica Rozalia Cywińska (Borkowska M. 2004, s. 38). O Cywińskiej w aktach luźnych - AAG, A. Cap. Luzy O 16, k. 6; informacje o urzędach - Przybyłowicz O.M. (w przygotowaniu).

8 Przybyłowicz O.M. 2012, s. 456-462; Przybyłowicz O.M. 2013c, s. 552-559; Przybyłowicz O.M. 2019, s. 317 i n.

9 Przybyłowicz O.M. 2013b, s. 179-194; Przybyłowicz O.M. 2014, s. 138-149; Przybyłowicz O.M. 2016, s. 247-263; Przybyłowicz O.M. 2017b, s. 313-326.

${ }_{10}$ Przybyłowicz O.M. 2017a, s. 450 i n.; AAG ZKG 3, Księgi 1609.

11 AAG Regestrum. 1593. 
nad dochodami klasztoru w XVI w. wnosi Liber beneficiorum archidiecezji gnieźnieńskiej Jana Łaskiego z początku tego stulecia. Informacje o dobrach klarysek ograniczają się tam do stwierdzeń, która wieś należała do zakonnic; niekiedy autor wspomina o rodzaju obciążeń mieszkańców danej wsi, głównie jednak wobec parafii gnieźnieńskich, nie zaś klasztoru ${ }^{12}$.

Dane uzyskane z „Regestrum 1593” pozwalają na ustalenie jedynie pewnych grup przychodów, być może najważniejszych, ale nie ukazują całości funkcjonowania gospodarki wspólnoty. Brak bowiem w rejestrze tych wszystkich pozycji, które zasilały budżety klasztorów już od średniowiecza. Zaliczały się do nich: różnorodne formy darowizn (legaty, fundacje mszalne, naturalia), posagi (choć zgodnie z prawem nie były one wymogiem koniecznym do wstąpienia do zgromadzenia św. Klary) oraz inne, które wskazywały na aktywną działalność samej wspólnoty: dzierżawy, udzielanie pożyczek i kredytów, zakup czynszów (co czyniły w średniowieczu np. klaryski i dominikanki wrocławskie) $)^{13}$.

Rękopis z roku 1593 nie ma oprawy ani karty tytułowej. Został spisany przez jedną osobę (na co wskazuje dukt pisma), choć w kilku miejscach zawiera dopiski i uzupełnienia czynione innymi rękoma. To, wraz z dość starannym opracowaniem danych wskazuje, iż jest to czystopis powstały zapewne na podstawie brudnopisu lub luźnych notatek czynionych podczas objazdu dóbr zakonnic. Nie wiadomo, kto był jego autorem — prokurator wspólnoty, osoba świecka czy duchowny, być może franciszkanin przeprowadzający na polecenie władz zakonu wizytację w konwencie. Z tego okresu mamy wiadomości o pobycie w Gnieźnie komisarza, później ministra prowincji polskiej, Jerzego Benignusa Doglioni z Belluno. Gościł on w klasztorze Ubogich Panien w latach 1583 i 1593, o czym świadczy kodeks zawierający regułę i konstytucje: „Co dla lepszego porządku i wiary, pieczęcią urzędu naszego umacniamy i ręką własną podpisujemy. Actu $[\mathrm{m}]$ et datu $[\mathrm{m}]$ in eodem conventu 9 Augusti Anno D[omi $]$ ni $1593{ }^{\prime \prime 14}$. W konstytucjach pozostawionych klaryskom gnieźnieńskim, które „Zebrane częścią z Concilium Trydenskiego częścią z statutów kapituły główny florenski od najwyszego[?] papieża Piusa czwartego wybranych i utwierdzonych", dwa punkty dotyczyły gospodarowania dobrami przez wspólnotę św. Klary ${ }^{15}$. Można zatem przypuszczać, że data sporządzenia „Regestrum 1593” nie jest przypadkowa i trzeba ją zapewne wiązać z zaleceniami soboru i kapituły tyczącymi zarządzania majątkiem i gospodarowania, a przede wszystkim z wizytą tego przełożonego. W tekście konstytucji, podobnie jak w zestawieniu czynszów i dochodów, nie zostało wymienione nazwisko ksieni. Jednak z informacji znajdujących się w aktach luźnych przechowywanych w zbiorach

12 Nie zostały wymienione wszystkie dobra klarysek, Liber beneficiorum. 1880-1881, s. 12: Item Piekary, praedium monialium monasterii gnesnensis, de cuius preadii Agros omnibus et singulis decima manipularis proveniens, pertinets spectatque ad ecclesiam praedictam $S$. Laurentii. Et aestimatur walor aliquando ad unam marcam, aliquando magis et aliquando minus; s. 18: Obora, villa monialium gnesnensium, sub parcochia s. Petri, cuius quidem villa cmethones et incolae omnes et singli dicta ecclesiae et eius pro tempore plebano nihil aliud solvunt, soum missalia, videliset de quodlibet manso seu laneo per duas mensura frumentorum, unam videlicet siliginis et alima avenae. Hortulani vero solvunt per forum avenae, et conducit ea plebanus curru proprio.

13 Manikowska H. 2002, s. 15 i n.; Manikowska H. 2006, s. 207-223; Oliński P. 2013, s. 200 i n.

14 AAG ZKG 1, Reguła i Konstytucje 1593.

15 AAG ZKG 1, Reguła i Konstytucje 1593, k. 13r i v. W punkcie VII zalecił: by użytki z folwarków klasztoru były obracane w dobro wspólnoty: ,i z nich [ksieni — O.M.P.] liczbę uczyni przed wszytkimi pannami zakonnemi. Jeśliby się tedy więtszy części Panien zdało (przy obecności i zdaniu ojca prowincjała, a nie inaczej), mają je arendować do trzech lat [...]". W VIII zalecał ksieni naradzanie się ze starszymi w sprawach zarządzania dobrami, ,a gdyby się przytrafiło pieniądze od arendarzow być niesione do klasztora, ksieni sama niech nie bierze pięniedzy, ani się Panny więcej zakonne pieniędzmi nie dzielą, ale w jakij skrzy[n]ce mają być schowane, do który mają być trzy klucze z których jeden niech ma ksieni, a drugie dwa szafarki niech trzymają. I z dochodów także i wydatków, które w księgach przystojnych będą pisane na każdy miesiąc przed starszym i rachunek będą czynić, aby wiedziano, w którym by postanowieniu był klasztor". 
AAG wiadomo, że urząd ten pełniła wówczas Zofia Kozielska, która w dokumentach klasztoru pojawiła się jako szeregowa zakonnica już w roku $1548^{16}$.

We wspomnianym rękopisie na sześciu paginowanych kartach (pozostałe trzy niezapisane) odnotowano należności w naturaliach i czynsze od poddanych klarysek zamieszkujących dobra wiejskie należące do konwentu oraz dochody z miasta Kostrzyna i z samego Gniezna. Lista wsi wchodzących w skład majątku klasztoru pod koniec XVI w. wskazuje, iż zakonnice utrzymały, a nawet nieco powiększyły uposażenie z pierwszych dekad istnienia.

Podstawę bytu wspólnoty stanowiły dobra ziemskie, które zgodnie z regułą klarysek zatwierdzoną przez papieża Urbana II w 1264 r., mógł posiadać każdy konwent (za wyjątkiem kilku klasztorów, które zachowały regułę św. Klary z 1253 r.) pod warunkiem, że stanowiły one własność wspólną, a dochody należały do całego klasztoru. W XIII w. zakonnice uzyskały od księcia Przemysła II (według zachowanych dokumentów to on, nie zaś Bolesław Pobożny był fundatorem ${ }^{17}$ ): Winiary, Oborę, Woźniki, Żerniki, Łaszcze z jeziorami Długie, Bielsko, Mielno (wszystkie w okolicach Gniezna), z poddanymi i wszelkimi pożytkami z nich płynącymi, Brudzewo w kasztelanii puckiej od Mściwuja $\mathrm{II}^{18}$ oraz od Władysława Łokietka miasto Kostrzyn z prawem patronatu i należącymi do niego wsiami: Wybiartowo, Strumiany (w źródłach i literaturze przedmiotu także jako Stroniany), Siedlec, Grotkowo (w źródłach i literaturze przedmiotu także jako Grodkowo, Grotkowice) z wszystkimi przynależnościami i prawem budowy grobli, młynów, pasiek w lesie książęcym Moków oraz źreb Duba (sors Dubonis) ${ }^{19}$. Siostry wraz z bożogrobcami sprowadzonymi ok. 1179 r. do Gniezna były także współwłaścicielkami Grzybowa - wsi leżącej na północny wschód od miasta (w XVI w. była to już jurydyka) ${ }^{20}$. Pod koniec XVI w. w posiadaniu konwentu, spośród wyżej wymienionych dóbr, nie było jedynie Brudzewa, zanikłej wsi Łaszcze oraz źrebu Duba.

Ostatni Piastowie nie przyczynili się do powiększenia własności ziemskiej klasztoru ${ }^{21}$. Władysław Jagiełło, założyciel nowej dynastii, potwierdził dawne przywileje konwentu, dodając dochody z targowego w Gnieźnie ${ }^{22}$. W czasach nowożytnych kolejni monarchowie, począwszy od Zygmunta Starego, a skończywszy na ostatnim polskim władcy, Stanisławie Auguście Poniatowskim, przede wszystkim potwierdzali nadania poprzedników, o czym świadczą 23 oryginalne dokumenty królewskie oraz liczne ich kopie i odpisy przechowywane w AAG ${ }^{23}$. Zygmunt Stary, jako jeden z niewielu władców, nie tylko poświadczył na prośby wspólnoty dawne przywileje (m.in. te utracone w pożarze Gniezna w 1511 r., jak np. przywilej Aleksandra Jagiellończyka z 1504 r.), ale uczynił nowe nadania. Klaryski otrzymały od niego prawo patronatu w kościele w Strzyżewie oraz wsie — Mieniszewo (w źródłach także jako Miniszewo, Mniszewo),

16 Borkowska M. 2004, s. 25, wymieniła ją na urzędzie tylko w 1581 r. W dokumentach po raz ostatni wspomniana jest w tej roli w roku 1596 (AAG, A. Cap. Luzy O 36, k. 67, 69). Wybrana pod koniec 1596 r. nowa przełożona Anna Dębicka/Dębieńska formalnie objęła urząd w 1597 r., po konfirmacji dokonanej przez wizytatora Jana Donato Caputo (AFKrak. Visitatio. 1596, s. 365).

17 Jasiński K. 1984-1985, s. 730-733; KDW. 1877, t. I, nr 550. Przemysł II w pierwszym dokumencie uposażającym wspólnotę św. Klary stwierdził, że klasztor został przez niego wybudowany. Moim zdaniem wskazuje to na osobę fundatora i czas założenia.

18 KDW. 1877, t. I, nr 736; AAG, A. Cap. Luzy O 14, k. 4, 23. Był synem Świętopełka i Eufemii, córki księcia wielkopolskiego Władysława Odonica, siostry Bolesława Pobożnego, Śliwiński B. 2016; KDW. 1877, t. I, nr 556. Nadanie uczynił na prośby księżnej Jolenty.

19 KDW. 1877, t. I, nr 783; AAG, A. Cap. Luzy O 14, k. 23. Zwolnienia identyczne jak w pierwszych przywilejach dla klasztoru nadanych przez księcia Przemysła.

20 Dzieje Gniezna. 1965, s. 158.

${ }^{21}$ W 1372 r. Elżbieta Łokietkówna transumowała dokumenty Przemysła II i Łokietka, KDW. 1877, t. I, nr 1666.

22 W latach 1430 i 1433, AAG, A. Cap. Luzy O 14, k. 4, 23.

23 Przybyłowicz O.M. 2019b, s. 463-483. 
Szczodrochowo, Krzyszczewo (w źródłach także jako Krzeszczewo, Chrzeszczewo) i Piekary, ponadto zwolnił dobra oraz klasztor od wszystkich podatków królewskich i ziemskich ${ }^{24}$. Tak ukształtowany przez trzy stulecia majątek zgromadzenia w Gnieźnie potwierdza rejestr dochodów i czynszów z 1593 r. oraz Liber beneficiorum Jana Łaskiego ${ }^{25}$.

Trudno stwierdzić, na ile źródło gnieźnieńskie było typowym, na ile zaś wyjątkowym rękopisem o charakterze gospodarczym powstałym w klasztorze mendykanckim. W polskiej literaturze przedmiotu brak bowiem opracowań odnoszących się do kwestii dochodowości dóbr konwentów żeńskich w epoce nowożytnej wykorzystujących tego typu źródła. Również w odniesieniu do męskich wspólnot ustalenia w tym temacie są niedostateczne, a analizy na podstawie zachowanych inwentarzy dóbr dotyczą głównie XVIII i XIX w. ${ }^{26}$

Dane zawarte w „Regestrum 1593” zawierają, w przypadku dóbr wiejskich wspólnoty w Gnieźnie, podobne informacje jak te odnotowane w inwentarzu cystersów mogilskich z 1560 r., ale nie są tak kompletne i dokładne ${ }^{27}$. Artykuł o dochodach wspólnoty w Mogile to jedyny w literaturze przedmiotu szczegółowy przegląd grup przychodów klasztornych w XVI stuleciu opracowany na podstawie źródeł inwentarzowych, dlatego traktuję go jako tło porównawcze do informacji zebranych z rejestru klasztoru klarysek z Gniezna. Zdaję sobie jednak sprawę, że intensywna gospodarka cysterska to inna skala dochodów i organizacji dóbr niż w przypadku żeńskiej wspólnoty mendykanckiej. Z uwagi na fragmentaryczność informacji, niemożliwe jest użycie w celach porównawczych szesnastowiecznego rękopisu dotyczącego dóbr bożogrobców w Miechowie ${ }^{28}$.

W rękopisie opisującym majątki Ubogich Panien pod nazwą każdej wsi umieszczono informację o liczbie sołtysów i kmieci, następnie wymieniono poddanych z imienia lub przezwiska, podając przy każdym stawkę czynszu pieniężnego. Następnie odnotowano świadczenia w naturaliach oddawane z każdego śladu, czyli obszaru równego 14 hektarom, lub uprawianej roli, w końcu prace wykonywane na rzecz pana feudalnego — konwentu ${ }^{29}$. Te ostatnie dane są nieprecyzyjne - po pierwsze nie zapisano, z jakiego nadziału ziemi były one wykonywane, po drugie lakonicznie opisano obowiązki kmieci, umieszczając najczęściej formułę: „Dni robotne powinni jako i w jinszych wsiach" ${ }^{30}$. Poza kmieciami i sołtysami nie uwzględniono w zasadzie innych grup ludności wiejskiej, co stanowi poważną lukę przy próbie podjęcia badań nad strukturą społeczną poddanych w dobrach zakonnic. Tylko raz wspomniano (bez podania liczby), że

${ }^{24}$ AAG, A. Cap. Luzy O 14, k. 7, dokument opatrzony pieczęcią większą królewską, częściowo uszkodzoną.

${ }_{25}$ Liber beneficiorum. 1880-1881, t. I, s. 11-15, 18.

${ }^{26}$ Z pierwszej połowy XVII w. pochodzą pojedyncze karty inwentarzy, np. z cysterskiego klasztoru w Szczyrzycu zachowała się zaledwie jedna karta z 1645 r., która zawiera wyłącznie dane o zabudowaniach folwarku w samym Szczyrzycu. Inwentarze z pełniejszymi danymi, które stały się podstawą do badań nad gospodarką tego klasztoru, pochodzą dopiero z lat 1741, 1763 oraz 1827 i 1868 r. (Marszalska J. M. 2011, s. 110-111; Marszalska J. 2013, s. 28). Z klasztoru karmelitów bosych w Czernej założonego w 1631 r. zachował się inwentarz folwarków z 1643 r., zawierający dane na temat zobowiązań kmieci, wielkości gospodarstw i budynków. Niestety w monografii nie zaprezentowano analizy danych, wymieniając ogólnie zwierzęta hodowlane i budynki. Analiza szczegółowa została przeprowadzona dopiero na podstawie inwentarza z roku 1834 r. (Graczyk W., Marszalska J.M. 2014, s. 80-81). Trudno porównywać realia XVIII i XIX stulecia do tych z końca XVI w.

${ }_{27}$ Podano liczbę łanów pustych i osiadłych, stawkę czynszu pieniężnego i naturaliów oddawanych z łana, wymiar pańszczyzny i innych prac, imiona i przydomki chłopów, nadziały ziemi, Zdanek M. 2013, s. 260 i n.

${ }^{28}$ Rękopis wzmiankowany jest przez Jerzego Rajmana. Autor nie zamieścił jednak żadnej informacji o zawartości inwentarza, ograniczając się do stwierdzenia, iż jest „,niezwykle cenny”, zaś zebrane na jego podstawie dane prezentowane w tekście dotyczą jedynie kategorii poddanych w wybranych (a więc nie wszystkich) wsiach klasztoru w latach 1565-1574, Rajman J. 2013, s. 414, 423 (tabela z liczbą poddanych), 424 (ogólnie wymieniono najbardziej popularne uprawy), 428 (ogólnie wymieniono gatunki zwierząt hodowlanych).

${ }_{29}$ Stownik Staropolski. 1973-1980, t. VII, s. 18.

30 AAG Regestrum. 1593, s. 3. 
zagrodnicy są w Woźnikach i Żernikach. Trudno zatem rozstrzygnąć, czy w innych wsiach nie było np. komorników bądź chałupników, czy też po prostu pominięto te grupy poddanych, podobnie jak w inwentarzu cystersów mogilskich z roku $1560^{31}$. W źródle wzmiankowano też przy określonej wsi o istniejących folwarkach panieńskich, jeśli się tam znajdowały. Brak natomiast danych o dziesięcinie snopowej i zbożowej.

Kmiecie przekazywali do klasztoru owies, pszenicę, żyto, kury, kapłony i jaja w zróżnicowanej objętości i liczbie. Płacili też różne stawki czynszów. Sołtysi wsi w dobrach klarysek mieli natomiast te same obowiązki: płacili 12 gr wiecnego i stawiać się mieli „na drogę”, gdy klasztor wydał takie polecenie. Były też wsie, z których do klasztoru przekazywano również gotówkę (z Grotkowa 80 zł) (tab. 1).

Wpływów konwentu klarysek, w przeciwieństwie do przychodów cystersów w Mogile, nie powiększały czynsze z karczem i browarów ${ }^{32}$. Karczmarz klarysek ze Strzyżewa był „wolen od podatków, jedno wapno robić, gdy gruntu dostaną do materyi za umową z niem postanowioną" 33 .

Młyny także nie były traktowane przez zakonnice jako potencjalne, niemałe - jak przekonują inwentarze cysterskie - źródło przychodów pieniężnych. Z istniejącego przy folwarku na Piekarach wiatrowego siostry miały jedynie „dwie z mierze zboża wszelakiego, a trzecia młynarzowi”. Podobnie było w Strzyżewie, gdzie stał młyn o dwu kołach korzecznych ${ }^{34}$. Młynarz na Piekarach nie oddawał czynszu, ale był zobowiązany do określonych usług — „wedle przywileju powinien w konwencie starych rzeczy poprawić kiedy rozkażą”, zaś strzyżewski płacił należność z ról pustych w wysokości 2 złotych i 12 groszy $^{35}$. Z młyna słodowego końskiego w Kostrzynie klasztor także nie uzyskiwał gotówki, lecz „miary słodowe, z których konwent ma w piwie opatrzenie", natomiast inny, znajdujący się tam młyn, w którym mielono słody gorzałczane, przynosił 22 złote czynszu rocznie ${ }^{36}$

Folwarki znajdowały się w dobrach klarysek pod Kostrzynem, w Woźnikach, Oborze i na Piekarach. Budynki gospodarcze (obory, szopy, owczarnie, stodoły) były w większości w dobrym stanie, podobnie jak zabudowania mieszkalne. Tylko w niektórych przypadkach ich wygląd budził zastrzeżenia osoby spisującej rejestr. W odniesieniu do infrastruktury gospodarstwa folwarcznego w Oborze zapisano np.: „Izba niegorsza, komora, z niej sień i dwie komorze sienne stare, niedobre. Mlecznik niezły. Obory dobre. Owczarnia stara. Dwie stodole o dwu bojewiskach, jedna nowa, druga stara, poszycie i z wrotami" ${ }^{37}$. Hodowano przede wszystkim owce, bydło, świnie i gęsi.

Nie można oszacować dochodów folwarków, gdyż w omawianym źródle nie ma żadnych danych umożliwiających takie obliczenia — brak nie tylko wzmianek o areale, ale także o wysokości pańszczyzny sprzężajnej, która — jak wykazał Andrzej Wyczański — mogła być jednym z wyznaczników wielkości areału folwarcznego ${ }^{38}$ (tab. 2).

Dokładniejsze informacje o dochodach wspólnoty znalazły się przy opisie Kostrzyna, miasta założonego w 1251 r. przez księcia Przemysła I ${ }^{39}$, darowanego konwentowi przez księcia

31 Sporadycznie wymieniano zagrodników, a zupełnie pominięto komorników, Zdanek M. 2013, s. 262.

32 Zdanek M. 2013, s. 265.

33 AAG Regestrum. 1593, s. 11.

${ }^{34}$ AAG Regestrum. 1593, s. 10, 11.

35 AAG Regestrum. 1593, s. 10.

${ }^{36}$ AAG Regestrum. 1593, s. 1.

${ }^{37}$ AAG Regestrum. 1593, s. 9.

38 Wyczański A. 1960, s. 70 i n. M. Zdanek zwrócił uwagę na problem braku danych o dochodach z folwarków, a więc gospodarki własnej cystersów, Zdanek M. 2013, s. 262.

39 KDW. 1877, t. I, nr 296: iure theutonico, eo videlicet quo hospites nostri in Rogosne utuntur. Po trzech latach wolnizny mieli płacić z łanu wiardunek srebra, trzy miary trzech zbóż, jako dziesięcinę od działek i od 


\begin{tabular}{|c|c|c|c|c|c|c|c|c|c|c|c|c|c|c|c|}
\hline & & & 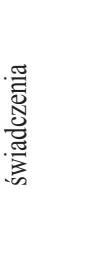 & & 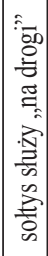 & 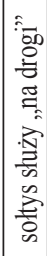 & 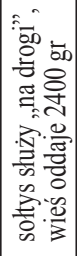 & 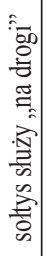 & & & & 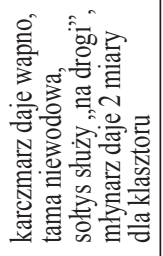 & 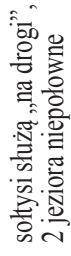 & & 京 \\
\hline & & & 产 & & & & & - & - & & - & & & - & F \\
\hline & & & 蚫 & $\sqrt[6]{6}$ & \& & \& & 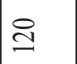 & 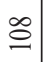 & లి & ఫ & & 8 & & & 통 \\
\hline & & 票 & 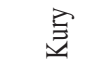 & & $\infty$ & & & $\infty$ & 寸 & \pm & & 6 & 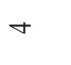 & & $\stackrel{t}{0}$ \\
\hline & $\Xi$ & & 空总 & $\widetilde{\sim}$ & & 0 & $\infty$ & & & & & & & & in \\
\hline 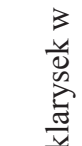 & D & & $\sum_{0}^{0.0}$ & 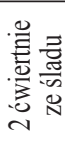 & 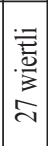 & 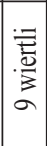 & & 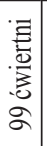 & & 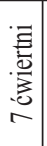 & & & 苞 & & 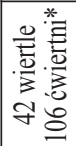 \\
\hline 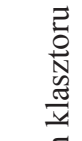 & 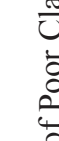 & . & 跑 & & & & & 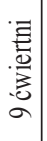 & 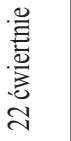 & & & & & & 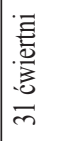 \\
\hline 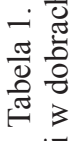 & 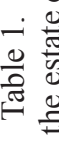 & & 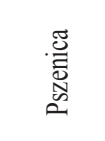 & & 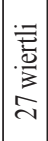 & 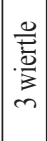 & & 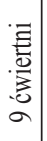 & 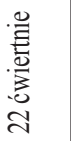 & & & & & & 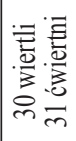 \\
\hline 3 & 8 & & 怘 & & $\bar{\imath}$ & $a$ & & જ & 고 & $\vec{\sim}$ & & & 0 & & 守 \\
\hline 总 & त & & 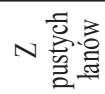 & & $\widetilde{\sigma}$ & $\triangleright$ & & 㠻 & & & & $\mathbb{N}$ & $\curvearrowleft$ & & $\frac{\nabla}{\sim}$ \\
\hline . & 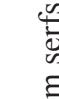 & 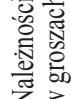 & ¿ & $\widetilde{\sim}$ & $\infty$ & 6 & $\infty$ & $\begin{array}{l}\stackrel{\Xi}{\Xi} \\
\stackrel{\Xi}{\Delta}\end{array}$ & $\curvearrowleft$ & \pm & & 0 & $\nabla$ & & $\begin{array}{l}\stackrel{N}{\Xi} \\
\stackrel{i n}{=}\end{array}$ \\
\hline . & 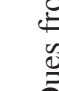 & & 总 & 㐘 & $\approx$ & $\tilde{2}$ & లో & 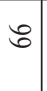 & & $\frac{\infty}{0}$ & & $\stackrel{\circ}{n}$ & ఫ & & 㗕 \\
\hline & & & 自 & & & & & & $\begin{array}{l}\text { 总 } \\
\text { 惫 } \\
\text { 잉 }\end{array}$ & & & 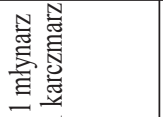 & & & in \\
\hline & & $\frac{\pi}{8}$ & 窝 & & - & - & - & - & & & & - & $\sim$ & & $r$ \\
\hline & & & 离. & $=$ & $a$ & $m$ & t & $a$ & $\approx$ & - & & $m$ & $\sim$ & & 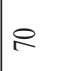 \\
\hline & & & & 忩 & 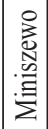 & 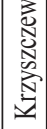 & 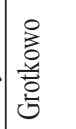 & 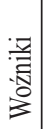 & $\begin{array}{l}\pi \\
0\end{array}$ & 竧 & 昰 & 总 & 密 & 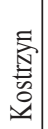 & 急 \\
\hline
\end{tabular}


Tabela 2.

Żywy inwentarz i budynki w folwarkach klarysek w $1593 \mathrm{r}$.

Table 2.

Lifestock and buildings in Poor Clares' farms in 1593

\begin{tabular}{|c|c|c|c|c|c|c|c|c|c|}
\hline \multirow[b]{2}{*}{ Folwark } & \multicolumn{7}{|c|}{ Żywy inwentarz } & \multirow[b]{2}{*}{ Budynki } & \multirow[b]{2}{*}{ Ogrody } \\
\hline & krowy & jałowice & cielęta & $\begin{array}{l}\text { owce/ } \\
\text { jagnięta }\end{array}$ & świnie & konie & gęsi & & \\
\hline Kostrzyn & 4 & 7 & 3 & $30+20$ & 15 & 3 & 27 & $\begin{array}{l}1 \text { stodoła } \\
1 \text { młyn } \\
\text { domy i szopy } \\
\text { (bez liczby) }\end{array}$ & \\
\hline Woźniki & 8 & 14 & 5 & 79 & 11 & & 43 & $\begin{array}{l}1 \text { owczarnia } \\
1 \text { dom } \\
\text { obory, szopy } \\
\text { (bez liczby) }\end{array}$ & 2 \\
\hline Obora & 9 & 14 & 7 & 114 & 18 & & 77 & $\begin{array}{l}1 \text { izba z komorami } \\
1 \text { mlecznik } \\
1 \text { owczarnia } \\
2 \text { stodoły } \\
\text { obory (bez liczby) }\end{array}$ & \\
\hline Piekary & 10 & 10 & 2 & 158 & 18 & & 38 & $\begin{array}{l}1 \text { nowy dom } \\
1 \text { obora } \\
2 \text { stodoły } \\
1 \text { owczarnia } \\
1 \text { młyn wiatrowy, } \\
\text { z którego } 2 / 3 \text { miary } \\
\text { dla klasztoru } \\
\text { szopy (bez liczby) }\end{array}$ & \\
\hline Suma & 31 & 45 & 17 & $\begin{array}{l}381 \text { owiec } \\
\text { i } 20 \text { jagniąt }\end{array}$ & 62 & 3 & 185 & & 2 \\
\hline
\end{tabular}

Władysława Łokietka w 1298 r. Miejscowość otrzymała od klarysek prawo magdeburskie w roku $1477^{40}$, w którym to dokumencie wymieniono należności mieszkańców wobec klasztoru. Były one niższe niż te pobierane de facto w roku 1593. Pod koniec XVI w. z każdej z 46 osiadłych włók kostrzynianie płacili czynsz roczny w wysokości grzywny, co dawało w sumie 73 złote (każdy złoty zawierał 30 groszy) i $18 \mathrm{gr}^{41}$. W „Regestrum 1593” uwzględniono też nowe pozycje dochodów, które nie zostały wymienione w dokumencie z XV stulecia: szos, ogrody, kwoty od rzemieślników i z jarmarku oraz targowe, z młyna końskiego i z jeziora, ponadto kucharne (które wynosiło złoty i 16 gr) ${ }^{42}$ oraz podworowe „z każdego domu po groszu jednemu” (co

domu po pół skojca srebra, z sądownictwa 1/3 dochodów należała do sołtysa, a 2/3 do panującego, Słownik historyczno-geograficzny. 1991, s. 330.

${ }^{40}$ Zachował się insert dokumentu wystawionego przez ksienię Katarzynę Zagajewską (II) (Borkowska M. 2004, s. 22). Wpisano go do przywileju spisanego w języku polskim 1 XII 1588 r., w celu wciągnięcia aktu, na prośbę Marcina i Tomasza Tarasa, mieszczan kostrzyńskich, „burmistrza, rajców, wójta, ławnika i wszystkiego pospólstwa tegoż miasteczka Kostrzyna imieniem", do akt grodzkich miasta Poznania. Odpis dokumentu pomieszczony w „Księdze wszystkich spraw” (AAG, Księgi 1609, s. 503-506) oraz w aktach luźnych klarysek (AAG, A. Cap. Luzy O 36 Kostrzyn i Strumiany I: 1427-1599 [1763], k. 6 (a-f)). Karol Ney wydał tekst z opuszczeniami i złym odczytem w kilku miejscach (Ney K. 1843, s. 80-82), Przybyłowicz O.M. 2014, s. 141 i n.

41 Według przywileju z 1477 r. z każdego z 42 i pół śladu płacili grzywnę, i dodatkowo z każdej grzywny grosz kucharnego.

42 Danina płacona najprawdopodobniej na utrzymanie kuchni klarysek lub ich poddanych w folwarku podkostrzyńskim. Analogicznie w połowie XVII w. notowano w lustracjach królewskich „kuchenne” — daninę 
dawało 4 złote i 6 gr) ${ }^{43}$. Oznacza to, że w Kostrzynie było wówczas 126 domostw. Szos miał być płacony dwukrotnie w ciągu roku, chociaż w analizowanym źródle wymieniono najpierw kwotę regulowaną na Świątki, czyli na święto Zesłania Ducha Świętego, o wartości 6 zł i 27 gr. Inną ręką natomiast dopisano informacje o wysokości opłat $\mathrm{z}$ tego tytułu w dwóch terminach — na Świątki gr 8 i na świętego Bartłomieja (czyli 24 sierpnia) także 8 gr ${ }^{44}$. Pod Kostrzynem, na tzw. Rypinach, było 20 ogrodów, a ich użytkowanie dawało klasztorowi po 4 grosze, czyli łącznie 2 złote i $20 \mathrm{gr}^{45}$.

Mieszczanie przekazywali daniny w naturaliach: owies „według zwyczaju dawnego sześć małdrów przed dwu wiertlum ${ }^{46}$ " miary gnieźnieńskiej na drugą niedzielę Wielkiego Postu, oraz w tym dniu 32 kopy jaj, a także jeden złoty i 6 gr na masło ${ }^{47}$. Na Boże Narodzenie oddawano kury - 130 sztuk i dodatkowo z ogrodów rypińskich — 54, oraz „na pieprz” groszy 36 . Szewcy płacili rocznie 8 zł, zduni - 4 zł, mielcarze żytni - grzywnę. Rzeźnicy oddawali 3 i pół kamienia łoju, zaś młynarz płacił $22 \mathrm{zl}^{48}$. Targowe i wiecne, czyli prandialium ${ }^{49}$, dawało kwotę 2 zł i 16 gr, dwa jarmarki (na św. Piotra i św. Łukasza) — złoty i gr 19, zaś jeziorko pod miasteczkiem przynosiło dochód w wysokości $2 \mathrm{zł}^{50}$.

$\mathrm{Na}$ wójtostwie był ponadto folwark klasztorny, „w którym budowanie wedla potrzeby domostwa, szopy dobre, stodoła nowa wielka. Sprzęty domowe wedla potrzeby"51 (tab. 3).

W Gnieźnie przychody klasztoru stanowiły wpływy z targowego podczas dwóch jarmarków organizowanych w dniach św. Wojciecha i św. Bartłomieja, nadanych przez króla Jagiełłę w źródle nie podano wysokości, jak również z dwóch jatek mięsnych -4 zł, z czynszów z domów wynajmowanych m.in. Żydom w obrębie miasta, w pobliżu klasztoru ${ }^{52}-13$ zł i 18 gr, oraz z jakiś nieruchomości na przedmieściach, a także z ogrodów ulokowanych między wsią Winiary a Gnieznem ${ }^{53}$.

Dochód konwentu klarysek gnieźnieńskich zsumowany na podstawie prezentowanego źródła wynosił w 1593 r. 366 zł oraz 23 i pół grosza. Porównanie liczby wsi i folwarków, a co za tym idzie wysokości dochodów i czynszów oraz liczby zwierząt hodowanych w dobrach klarysek (tab. 2-3) z dostępnymi danymi z literatury przedmiotu — dóbr cysterskich, arcybiskupów gnieźnieńskich i tamtejszej kapituły, wskazuje na zupełnie inną skalę i charakter

na kuchnię podstarościego, choć tam była dawana przede wszystkim w naturaliach, Lustracja 1564, t. II, s. 718, 721-726, 728-729.

43 AAG Regestrum. 1593, s. 1.

44 Według przywileju z 1477 r. po 8 gr na Świątki i św. Bartłomieja.

45 AAG Regestrum. 1593, s. 1.

46 Wiertel to czwarta część korca (Słownik staropolski. 1973-1980, t. X, s. 187). Małdrat to jednostka objętości równa trzem korcom (Słownik staropolski. 1973-1980, t. IV, s. 148). Korzec to ok. 52-54 litrów (Szymański J. 2001, s. 169; Stownik staropolski. 1973-1980, t. III, s. 349).

${ }^{47}$ Według przywileju z 1477 r. było to 30 kop jaj kokoszych (1800 sztuk) i trzy wiardunki pieniędzy monety polskiej, owsa zaś 100 wiertli miary poznańskiej na „każde święto świąteczne”, czyli najprawdopodobniej na wyżej wymienione uroczystości kalendarza kościelnego.

48 Według przywileju z 1477 r. rzemieślnicy należący do cechów: rzeźniczego, krawieckiego, świeckiego, piekarskiego, ubogiego kuśnierskiego, garncarskiego, płócienniczego oraz innych, które miały zostać założone in spe, nie wnosili osobnych opłat, nie mieli jednak umniejszać „nic pożytków naszych i podatków”. Łój z trzynastu jatek — z każdej trzy i pół kamienia — na św. Marcina (11 listopada), wyliczono 47 kamieni, podczas gdy de facto było to 45 i pół kamienia (blisko $590 \mathrm{~kg}$ ), licząc kamień po 12,960 kg według systemu miar i mas z 1565 r., Szymański J. 2001, s. 172; AAG, Księgi 1609, s. 503.

49 Wiecne, czyli obiedne (prandialia) płacone w wysokości 12 lub 24 gr od całej wsi, lub 1-3 gr z gospodarstwa. Dodatkowo zwykle po 12 gr płacili sołtysi, Żytkowicz L. 1962, s. 356.

${ }^{50}$ AAG Regestrum. 1593, s. 1.

51 AAG Regestrum. 1593, s. 2.

52 Było to jednym z powodów konfliktu, który rozpoczął się na początku XVII stulecia.

53 Przybyłowicz O.M. 2017b, s. 315 i n. 
Tabela 3.

Czynsze i naturalia uzyskiwane przez konwent z Kostrzyna w 1593 r.

Table 3.

The convent's rents and dues in kind received from Kostrzyn in 1593

\begin{tabular}{|l|c|c|c|c|}
\hline \multicolumn{2}{|c|}{ Czynsz } & \multicolumn{2}{c|}{ Naturalia } \\
\hline Płatnicy / źródło dochodu & $\begin{array}{c}\text { Wysokość } \\
\text { (w groszach) }\end{array}$ & Płatnicy & Produkt & Wysokość / liczba \\
\hline z 46 włók po grzywnie & 2208 & mieszczanie & owies & 6 małdrów \\
\hline kucharne & 46 & mieszczanie & kury & 130 \\
\hline podworowe z 126 domów & 126 & mieszczanie & na pieprz & 36 groszy \\
\hline szos & 207 & z ogrodów z Rypina & kury & 54 sztuki \\
\hline ogrody & 80 & $\begin{array}{c}\text { z ogrodów } \\
\text { podmiejskich }\end{array}$ & jaja & $\begin{array}{c}32 \text { kopy } \\
\text { (1920 sztuk) }\end{array}$ \\
\hline szewcy & 240 & $\begin{array}{c}\text { z ogrodów } \\
\text { podmiejskich }\end{array}$ & na masło & 30 groszy \\
\hline zduni & 120 & $\begin{array}{c}\text { młyn słodowy } \\
\text { koński }\end{array}$ & $\begin{array}{c}\text { miary słodowe na } \\
\text { piwo dla konwentu }\end{array}$ & - \\
\hline z młyna słodowego końskiego & 660 & rzeźnicy & łój & półczwarta kamienia \\
\hline mielcarze & 48 & & & \\
\hline targowe i wiecne & 78 & & & \\
\hline jarmarki & 109 & & & \\
\hline z jeziora & 60 & & & \\
\hline Suma & 3982 & & & \\
\hline
\end{tabular}

gospodarczej działalności konwentu Ubogich Panien. Np. dochody pieniężne z czynszów z 15 wsi cystersów w Mogile w 1560 r. wynosiły ponad 888 zł, zaś dochody z sześciu folwarków ponad 1820 zł, a szacunkowy, całkowity dochód zamykał się kwotą 5200 z ${ }^{54}$. W każdym z 24 folwarków w dobrach arcybiskupich w Wielkopolsce hodowano w drugiej połowie XVI w. średnio 29 krów, 70 owiec i po kilkadziesiąt sztuk drobiu, zaś w folwarkach kapituły gnieźnieńskiej było w tym okresie średnio 25 sztuk rogacizny, 12 koni, 17 świni i 110 owiec $^{55}$.

Gospodarstwo wiejskie klarysek, w przeciwieństwie do majątku cystersów mogilskich ${ }^{56}$, oraz wielkiej własności ziemskiej należącej do arcybiskupa i kapituły gnieźnieńskiej, w minimalnym stopniu nastawione było na czerpanie zysków z produkcji rolnej i hodowli. Gospodarkę klarysek można, przy zachowaniu pewnej ostrożności, nazwać autarkiczną, gdyż wydaje się, że dochody z dóbr wiejskich i miejskich klasztoru w Gnieźnie przeznaczane były na potrzeby własne, na utrzymanie zakonnic i całej wspólnoty. Jedynie rozmiar hodowli owiec w folwarkach może wskazywać na czerpanie zysków z tej gałęzi gospodarki, tym bardziej, że w Wielkopolsce od drugiej połowy XVI stulecia rosło zapotrzebowanie na wełnę ${ }^{57}$. Brak rachunków z tego

${ }^{54}$ Zdanek M. 2013, s. 265-267.

55 Topolski J. 1958, s. 235, 238; Żytkowicz L. 1962, tab. 82.

56 Niezwykle obszerna literatura przedmiotu syntetycznie zebrana m.in. w pracach K. Charvatovej, zob. np.: Charvátová K. 2013, s. 334-345; Dobosz J., Wyrwa A.M. 1999, s. 189 i n.

${ }^{57} \mathrm{~W}$ drugiej połowie XVI w. w folwarkach wielkopolskich było o sto procent więcej owiec niż w folwarkach ziemi sieradzkiej i łęczyckiej, Topolski J. 1958, s. 290; Topolski J. 2010, s. 216-217. 
Tabela 4.

Dochody z Gniezna w 1593 r.

Table 4.

The income from Gniezno in 1593

\begin{tabular}{|c|c|}
\hline Źródło dochodu & $\begin{array}{l}\text { Wysokość } \\
\text { (w groszach) }\end{array}$ \\
\hline ogrody pod miastem & 270 \\
\hline dwa jarmarki & 2/3 całości dochodu \\
\hline jatki mięsne & 120 \\
\hline czynsz z domów żydowskich & 408 \\
\hline domki nad jeziorem & 30 \\
\hline Popowo & 48 (wyderkaf) \\
\hline Sokołowo & 48 \\
\hline Suma & $\begin{array}{c}924 \\
\text { (bez dochodu z jarmarków) }\end{array}$ \\
\hline
\end{tabular}

okresu nie pozwala jednak na określenie skali dochodów z tego tytułu, podobnie jak niemożliwe jest stwierdzenie, $w$ jakim stopniu czynsze i naturalia $z$ dóbr wiejskich oraz dochody miejskie wystarczały na zabezpieczenie bytu wspólnoty.

Na podstawie powyższych danych nie sposób też określić poziomu życia zakonnic i realnych dochodów konwentu, gdyż podane w tabelach (1-4) liczby, prezentujące świadczenia pieniężne i w naturaliach, stanowiły tylko jedno ze źródeł utrzymania. Być może było to źródło najważniejsze, ale były też inne, tworzące budżet każdego klasztoru, tj. wspomniane już powyżej zapisy, legaty, fundusze mszalne, darowizny i posagi.

Kolejną kwestią, która miała — oprócz wysokości dochodów — wpływ na poziom egzystencji Ubogich Panien, była wielkość zgromadzenia i familii klasztornej. Zachowane źródła pozwalają na oszacowanie wielkości wspólnoty; dostępne są dane o liczbie sióstr pod koniec XVI w., lecz dotyczą one wyłącznie zakonnic chórowych, nie zaś całej familii. Na podstawie wizytacji Jana Donato Caputo wiadomo, że podczas wyborów ksieni w roku 1595 (została nią wówczas Anna Dębicka) do głosowania było uprawnionych 14 zakonnic chórowych ${ }^{58}$. Do tej liczby należałoby dodać co najmniej kilka, być może nawet ok. 10 konwersek — sióstr wykonujących prace codzienne na rzecz zakonnic chórowych, poza tym kilka nowicjuszek oraz członków familii. Przez analogię do informacji zgromadzonych na podstawie analizy rachunków klarysek sądeckich z początku XVII stulecia, w których wymieniono familię klasztorną, można oszacować wielkość konwentu w Gnieźnie. Należy przypuszczać, że wśród osób utrzymywanych przez tamtejsze klaryski, którym zapewne płacono na suchedni (tak jak członkom familii w Starym Sączu) byli księża sprawujący posługę duchową, organista, kalkant (osoba poruszająca miechami organów), rzemieślnicy i czeladźs9. Mogło to być ok. 10, a nawet więcej osób. Dochody z dóbr wiejskich i miejskich klasztoru gnieźnieńskiego musiały więc zaspokoić codzienne potrzeby grona ok. 30-40 osób, a być może nawet liczniejszego. Od roztropności ksieni, jej doradczyń oraz prokuratora i rządców w folwarkach zależało w dużej mierze to, na jakim po-

58 AFKrak. Visitatio, k. 365; Przybyłowicz O.M. 2006, s. 273-274; Borkowska M. 2004, s. 26.

${ }^{59}$ Członkowie familii według listy wynagrodzeń klasztoru sądeckiego z listopada 1602 r. to czterej księża: Maciej, Stanisław, Bonifacy i Stanisław Tarczyn (dwaj pierwsi otrzymywali po 30 zł, dwaj następni po 20 zł), dzwonnik, kalkant, sześciu z czeladzi, rzeźnik, niejaki Frączek, Dorota pilnująca wrót i kucharka dla księży. Kwoty płacone familii to sumy od 3 zł do 6 gr, Percepta 1602-1604, k. 8v. 
ziomie materialnym funkcjonował konwent. Na poziom życia mieszkanek wspólnot św. Klary wpływ miały także inne czynniki, zwłaszcza koniunktura gospodarcza, ale także mniej lub bardziej rygorystyczne przestrzeganie litery prawa zakonnego oraz zaleceń potrydenckich, w tym konstytucji pozostawionych przez wizytatorów.

Adres Autorki:

dr Olga Miriam Przybyłowicz

Instytut Archeologii i Etnologii PAN

Al. Solidarności 105

00-140 Warszawa

olgamiriam@interia.pl

http://orcid.org/0000-0003-3422-550X

\section{BIBLIOGRAFIA}

\section{Źródla archiwalne}

Akta kościoła św. Trójcy. 1835-1871. „Akta kościoła św. Trójcy tyczące się zniesienia Klasztoru XX Franciszkanów i Panien Zakonnych w Gnieźnie 1835-1871”, Biblioteka Prowincji Franciszkanów w Gnieźnie, sygn. 31, s. 15-16.

Archiwum Archidiecezjalne w Gnieźnie [AAG].

Zakon Klarysek Gniezno, sygn. 1, Reguła i Konstytucje 1583-1603.

Zakon Klarysek Gniezno, sygn. 3, Księgi 1609 — „Księgi wszystkich spraw konwentu gnieźnieńskiego zakonu S. Klary. To jest katalog wszystkich sióstr zakonnych w tym klasztorze od pamięci ludzkiej professowanych żywych i zmarłych. Przytem inwentarz wszystkich dóbr prowentów także i przywilejów tegoż klasztoru za urzędu Wielebnej w Chrystusie Panny, Panny Doroty Bromierskiej, na ten czas Księniej tegoż klasztoru (acz niegodnej) uczynione, i pilnie pisane w roku pańskim 1609".

AAG Regestrum. 1593. „Regestrum censuum de bonis Monialium S[anctae] Clarae Gnesnensis 1593", AAG, Acta Capituli, sygn. B 811.

Archiwum Franciszkanów w Krakowie [AFKrak.].

Visitatio. 1596. „Visitatio tocius provinciae Maioris et Minoris Poloniae, Magni Ducatus Littuaniae Russiae etc. per Reverendum Patrem Magistrum Joannem Donatum Caputum a Cupertino Artium et Sacrae Theologiae Doctorem, eiusdem Provinciae Provincialem et Commissarium Generalem, Anno Domini 1596 die 5 Decembris, usque ad annum 1598", sygn. B-2.

Percepta 1602-1604. „Percepta 1602-1604”, Archiwum Klasztoru Klarysek w Starym Sączu, sygn. D.W. 1a.

\section{Źródla i opracowania publikowane}

Borkowska Małgorzata. 1992. Źródła do badań nad stanem majątkowym klasztorów żeńskich w Polsce w XVII-XVIII w., „Kwartalnik Historii Kultury Materialnej”, R. XL, nr 1, s. 33-39.

Borkowska Małgorzata. 2004. Leksykon zakonnic polskich epoki przedrozbiorowej, t. 1: Polska Zachodnia i Pótnocna, Warszawa.

Burdzy Dominika. 2013. „Percepta i expensa”. Budżety obu klasztorów dominikańskich w Sandomierzu w XVII w., [w:] Klasztor w gospodarce średniowiecznej i nowożytnej, red. M. Derwich, Wrocław, s. 319-332.

Charvátová Kateřina. 2013. Ekonomika cisterckých klášterů 12.-14. století, [w:] Klasztor w gospodarce średniowiecznej i nowożytnej, red. M. Derwich, Wrocław, s. 334-345.

Dochody i wydatki. 2002-2004. Dochody i wydatki Konwentu Braci Eremitów św. Augustyna przy kościele św. Katarzyny w Kazimierzu. Ze zbiorów Archiwum Państwowego w Krakowie, t. 1: 1502-1505; t. 2: 1506-1508, wyd. K. Jelonek-Litewka i in., Kraków. 
Dobosz Józef, Wyrwa Andrzej Marek. 1999. Działalność gospodarcza cystersów na ziemiach polskich - zarys problematyki, [w:] Monasticon Cisterciense Poloniae, t. 1-2, red. A.M. Wyrwa, J. Strzelczyk, K. Kaczmarek, Poznań, s. 189-212.

Dzieje Gniezna. 1965. Dzieje Gniezna, red. J. Topolski, Warszawa.

Felskau Christian-Frederik. 2013. Economy-related written sources of the Franciscans (and partially of the Poore Clare's) in Bohemia and Moravia, ca. 1230-ca.1450, „Hereditas Monasteriorum”, t. 3, s. 27-54.

Gąsiorowska Patrycja. 2010. Kuchnia i infirmeria w klasztorze klarysek krakowskich do końca XVIII wieku, [w:] Sanctimoniales. Zakony żeńskie w Polsce i Europie Środkowej (do przełomu XVIII i XIX wieku), red. D. Karczewski, A. Radzimiński, Z. Zyglewski, Bydgoszcz-Torun, s. 394-406.

Gąsiorowska Patrycja. 2011. Rola ksień klarysek krakowskich w zarządzie majątkiem ziemskim do końca XVIII w., [w:] Inter oeconomiam coelestem et terrenam. Mendykanci a zagadnienia ekonomiczne, Studia i Źródła Dominikańskiego Instytutu Historycznego w Krakowie, t. 9, red. W. Długokęcki i in., Kraków, s. 537-557.

Gąsiorowska Patrycja. 2013. Obrót gotówka w klasztorze żeńskim na przykładzie osiemnastowiecznych ksiag rachunkowych wybranych klasztorów krakowskich i lwowskich, [w:] Klasztor w gospodarce średniowiecznej i nowożytnej, red. M. Derwich, Wrocław, s. 303-318.

Graczyk Waldemar, Marszalska Jolanta M. 2014. Klasztor karmelitów bosych w Czernej od pierwszej połowy XVII do końca XIX wieku. Dzieje — kultura — ludzie, Warszawa.

Jasiński Kazimierz. 1984-1985. Przemyst, [w:] Polski Stownik Biograficzny, t. XXVIII, Kraków-Warszawa, s. 730-733.

Kaczmarek Krzysztof. 2013. Źródta do badań nad gospodarka klasztoru dominikanów we Wronkach, [w:] Klasztor w gospodarce średniowiecznej i nowożytnej, red. M. Derwich, Wrocław, s. $91-100$.

KDW. 1877. Kodeks dyplomatyczny Wielkopolski, wyd. I. Zakrzewski, t. I, Poznań.

Kubicki Rafał. 2013. Sources for the history of mendicant economy in Royal Prussia from 15th till the begining of the 16th century, „Hereditas Monasteriorum”, t. 3, s. 55-65.

Liber beneficiorum. 1880-1881. Jana Łaskiego Liber beneficiorum archidiecezji gnieźnieńskiej, wyd. J. Łukowski, t. I-II, Gniezno.

Little Lester K. 1978. Religious poverty and the profit economy in medieval Europe, London.

Lustracja województwa krakowskiego. 1964. Lustracja województwa krakowskiego 1564, cz. II, wyd. J. Małecki, Warszawa.

Mäkinen Virpi. 2001. Property rights in the late medieval discussion on Franciscan poverty, Leuven.

Manikowska Halina. 2002. Klasztor żeński w mieście średniowiecznym, „Roczniki Dziejów Społecznych i Gospodarczych", t. LXII, s. 7-50.

Manikowska Halina. 2006. Klasztor żeński w mieście średniowiecznym. Model funkcjonowania w Polsce i na Ślasku i weryfikacja tego modelu na przykładzie Wrocławia, [w:] Sociální svět středověkého města, red. M. Nodl, Praha, s. 207-223.

Marszalska Jolanta. 2011. Opactwo cystersów w Szczyrzycu od XIII do końca XX wieku. Dzieje - gospodarka - kultura, Kraków.

Marszalska Jolanta. 2013. Folwarki klasztoru cystersów w Szczyrzycu od XVII do XX w. w świetle zachowanych inwentarzy, „Architectus”, 3 (35), s. 27-45.

Michalski Maciej. 2006. Btogosławiona Jolenta - refleksja historyczno-hagiograficzno-historiozoficzna, [w:] Franciszkanie konwentualni i klaryski w Wielkopolsce od XIII do XIX wieku, red. T. Janiak, D. Stryniak, Gniezno, s. 71-82.

Ney Karol. 1843. Żywot błogosławionej Jolenty i kronika zakonnic Ś. Klary w Gnieźnie, Leszno.

Oliński Piotr. 2013. Atrakcyjność modlitewna a nadania i legaty na rzecz klasztorów funkcjonujących w późnośredniowiecznych miastach na przyktadzie Chetmna i Torunia, [w:] Klasztor w gospodarce średniowiecznej i nowożytnej, red. M. Derwich, Wrocław, s. 197-228.

Piwowarczyk Elżbieta. 2013. Pobożne legaty jako źródto dochodu klasztoru bernardynów w Krakowie w latach 1453-1530, [w:] Klasztor w gospodarce średniowiecznej i nowożytnej, red. M. Derwich, Wrocław, s. 209-228. 
Przybyłowicz Olga Miriam. 2006. Wizytacje klasztoru klarysek w Gnieźnie z lat 1595-1598, [w:] O rzeczach minionych. Scripta rerum historicarum Annae Rutkowska-Płachcińska oblata, red. M. Młynarska-Kaletynowa, J. Kruppé, Studia i materiały z Historii Kultury Materialnej, t. 71, Warszawa, s. 247-280.

Przybyłowicz Olga Miriam. 2011. Rachunki klasztorne jako źródło do poznania realiów życia klasztornego. Najstarsza księga rachunkowa klarysek ze Starego Sacza, [w:] Realia życia codziennego w Europie Środkowej ze szczególnym uwzględnieniem Śląska, red. A. Barciak, KatowiceZabrze, s. 107-130.

Przybyłowicz Olga Miriam. 2012. Archiwalia klarysek gnieźnieńskich w Archiwum Archidiecezji Gnieźnieńskiej, cz. 1: Sprawozdanie z kwerendy w dniach 29-31 VIII 2012 r., „Hereditas Monasteriorum", t. 1, s. 456-462.

Przybyłowicz Olga Miriam. 2013a. Jak panny zakonne rozliczały się? Księgi rachunkowe jako źródło do badań nad polskimi klasztorami żeńskimi w XVI-XVIII w., [w:] Klasztor w gospodarce średniowiecznej i nowożytnej, red. M. Derwich, Wrocław, s. 101-114.

Przybyłowicz Miriam Olga. 2013b. „Pamięć obłóczyn kożdy probantki”. Ceremonia obłóczyn w'świetle rękopisu Modus suscipiendi novitias ad habitum S. Clarae z 1600 r. z klasztoru klarysek gnieźnieńskich, „Hereditas Monasteriorum”, t. 2, s. 179-194.

Przybyłowicz Olga Miriam. 2013c. Archiwalia klarysek gnieźnieńskich w Archiwum Archidiecezji Gnieźnieńskiej, cz. 2: Sprawozdanie z kwerendy w dniach 9-12 VII 2013 r., „Hereditas Monasteriorum", t. 3, s. 552-569.

Przybyłowicz Miriam Olga. 2014. Zajac, dwa złote na pieprz i kary za gry hazardowe, Dwa przywileje klarysek dla miasta Kostrzyna z 1477 i 1615 r., [w:] Ecclesia Regnum Fontes. Studia z dziejów średniowiecza. Prace ofiarowane Profesor Marii Koczerskiej, red. zb., Warszawa, s. 138-149.

Przybyłowicz Miriam Olga. 2016a. Reguła zakonna jest wozem do nieba. Realia życia w klasztorach klarysek w Małopolsce, Wielkopolsce i na Ślasku, Warszawa.

Przybyłowicz Miriam Olga. 2016b. Rękopis Księgi wszystkich spraw Konwentu Gnieźnieńskiego zakonu S. Klary [...] pilnie pisane w roku pańskim 1609 i jego zawartość, „Hereditas Monasteriorum", t. 7, s. 247-263.

Przybyłowicz Olga Miriam. 2016c. Klasztor klarysek w Strzelinie - uposażenie, darowizny i dochody. Przyczynek do standardu życia wspólnoty w świetle prawa zakonnego i dokumentów, „Śląski Kwartalnik Historyczny Sobótka", R. LXXI, nr 2, s. 20-46.

Przybyłowicz Olga Miriam. 2017a. Źródła do poznania gospodarki w dobrach wiejskich klarysek gnieźnieńskich od końca XVI do schyłku XVII stulecia, „Kwartalnik Historii Kultury Materialnej”, R. LXV, nr 4, s. 446-460.

Przybyłowicz Olga Miriam. 2017b. „, Wolno będzie Żydom mieć okna szklane, w tych domach jednak żeby nieotworzyste...”. O wspótistnieniu konwentu klarysek z gmina żydowska w Gnieźnie w XVI-XVII wieku, [w:] Cum gratia et amicitia. Studia z dziejów osadnictwa dedykowane Pani Profesor Marcie Młynarskiej-Kaletynowej z okazji 65-lecia działalności naukowej, red. D. Adamska, K. Chrzan, A. Pankiewicz, Wrocław, s. 313-326.

Przybyłowicz Olga Miriam. 2019a. Źródła rękopiśmienne z klasztoru klarysek gnieźnieńskich w Archiwum Archidiecezjalnym Gnieźnie. Stan wiedzy, prezentacja spuścizny i możliwości badawcze, „Archiwa, Biblioteki, Muzea Kościelne”, R. 112, s. 317-336.

Przybyłowicz Olga Miriam. 2019b. Documents of the Polish Kings Issued for the Monastery of the Poor Clares in Gniezno (16th-18th centuries). Kings as the Protectors of the Convent, [w:] Orden und Stadt, Orden und ihre Wohltäter. Monastica historia 4, red. J.M. Havlík, J. Hlaváčková, K. Kollermann, Prag-St. Pölten, s. 463-483.

Przybyłowicz Olga Miriam. (w przygotowaniu). „Lista ksień konwentu gnieźnieńskiego i hierarchia urzędów w XVI-XIX w.".

Rajman Jerzy. 2013. Gospodarka w dobrach klasztoru bożogrobców miechowskich XV-XVI w. [w:] Klasztor w gospodarce średniowiecznej i nowożytnej, red. M. Derwich, Wrocław, s. 413-431.

Röhrig F. 1980. Die materielle Kultur des Chorherrenstiftes Klosterneuburg unter besonderer Berücksichtigung der Aussage von Rechnungsbüchern, [w:] Klösterliche Sachkultur des Spätmittelalters, Internationaler Kongress Krems an der Donau 18-21.9.1978, red. H. Appelt, Wien, s. 217-224. 
Romhanyi Beatrix. 2013. Les sources comptables, documents de gestion et d'administration des couvents mendiants en Hongie médéviale, „Hereditas Monasteriorum”, t. 3, s. 77-96.

Słownik historyczno-geograficzny. 1991. Słownik historyczno-geograficzny województwa poznańskiego w średniowieczu, t. II, z. 2, red. A. Gąsiorowski, Wrocław.

Stownik Staropolski. 1973-1980. Stownik Staropolski, t. III, IV, VII, IX, X, Wrocław.

Śliwiński Błażej. 2016. Mściwoj II (1224-1294): książe wschodniopomorski (gdański), Warszawa.

Szylar Anna. 2005. Działalność handlowa benedyktynek sandomierskich w XVIII i na poczatku XIX wieku, ,Studia Historyczne”, R. 48, z. 2, s. 167-189.

Szylar Anna. 2008. Gospodarowanie benedyktynek sandomierskich, Tarnobrzeg.

Szylar Anna. 2013. , Sprawa o tym, jak benedyktynki gospodarstwo prowadzity”. Organizacja i funkcjonowanie gospodarki benedyktynek w Sandomierzu w XVII i XVII w., [w:] Klasztor w gospodarce średniowiecznej i nowożytnej, red. M. Derwich, Wrocław, s. 447-460.

Szymański Jan. 2001. Nauki pomocnicze historii, Warszawa.

Topolski Jerzy. 1958. Gospodarstwo wiejskie w dobrach arcybiskupstwa gnieźnieńskiego w XVI do XVIII wieku, Poznań.

Topolski Jerzy. 2010. Handel Poznania w XVI-XVIII wieku, [w:] Varia historyczne. Jerzy Topolski, wstęp i wybór W. Wrzosek, Poznań, s. 194-218.

Wyczański Andrzej. 1960. Studia nad folwarkiem szlacheckim w Polsce w latach 1500-1580, Warszawa.

Zdanek Maciej. 2005. Folwarki cystersów małopolskich w średniowieczu, „Studia i Materiały do Dziejów Żup Solnych w Polsce", t. 24, s. 263-279.

Zdanek Maciej. 2009. Inwentarz dóbr i folwarków opactwa cystersów w Mogile, [w:] Folwark - Wieś —Latyfundium. Gospodarstwo wiejskie w Rzeczypospolitej w XVI-XVII wieku, red. J. Muszyńska, S. Kazusek, J. Pielas, Kielce, s. 173-185.

Zdanek Maciej. 2011. Dochody dominikanów krakowskich w 1. pot. XVI w., [w:] Inter oeconomiam coelestem et terrenam. Mendykanci a zagadnienia ekonomiczne, red. W. Długokęcki i in., Studia i Źródła Dominikańskiego Instytutu Historycznego w Krakowie, t. 9, Kraków, s. 259-271.

Zdanek Maciej. 2013. Dochodowość majątku klasztoru cystersów w Mogile w połowie XVI w. na podstawie inwentarza dóbr z lat 1560-1566, [w:] Klasztor w gospodarce średniowiecznej i nowożytnej, red. M. Derwich, Wrocław, s. 257-273.

Żytkowicz Leonid. 1962. Studia nad gospodarstwem wiejskim $w$ dobrach kościelnych $w$ XVI w., Warszawa.

Sources of income of the convent of Poor Clares in Gniezno at the end of the 16th c. on the basis of the "Regestrum 1593" manuscript

The article surveys rents, dues in kind and other revenues of the convent of Poor Clares in Gniezno from their country and town estates in the late 16th c. The analysis was based on the oldest register of income kept in the convent, preserved in the manuscript entitled "Regestrum censuum de bonis de bonis Monialium S[anctae] Clarae Gnesnensis 1593".

The manuscript registered dues from serfs from the country estates with which the convent had been endowed upon its foundation by Duke Przemysł II in the last decades on the 13th c., and from several other villages granted to the convent by King Sigismundus the Old in 1546 . The register also noted dues from the inhabitants of Kostrzyn, a town owned by the convent since the end of the 13th c. by the privilege of Duke Ladislaus the Elbow-high, and the convent's income from the town of Gniezno.

This document, however, is not sufficient to estimate the convent's real proceeds or the sisters' living standard, since the data in tables (1-4), representing dues in cash and in kind, cover only one of the many sources of the community's revenue. It may have been the most 
significant source, nevertheless, the Poor Clares, as any other religious community, had others, e.g. bequests, legacies, mass funds, donations and dowries. It seems that the income from the country and town estates was used to support the nuns and the whole convent community. Judging from its scale, sheep breeding may have been an additional source of income from the convent's farms, since the demand for wool grew in Greater Poland in the 2nd half of the 16th c. Still, the lack of accounts from that period precludes any estimation of proceeds from that source. Similarly, it is impossible to conclude whether rents and dues in kind were enough to support the community. By analogy to the model of functioning of other orders at that time it can be supposed that the convent in question was primarily supported by income from its landed estate, but due to the lack of other documents from the 2 nd half of the 16th c. it is impossible to describe in full the structure of the convent's revenues or the costs of supporting the community, including the servants, which at that time probably consisted of 30-40 people counting the servants.

Proofread by Izabela Szymańska 